\title{
Response of elite Kenyan finger millet (Eleusine coracana, L. Gaertn) genotypes to Ethrel application
}

\author{
Josephine Sarah Kunguni ${ }^{1, a}$, Damaris A. Odeny ${ }^{2, b^{*}}$, Otto G. Dangasuk ${ }^{1, c}$, \\ Lexa G. Matasyoh ${ }^{1, d}$, Chrispus O.A. Oduori ${ }^{3, \mathrm{e}}$ \\ ${ }^{1}$ University of Eldoret, P.O. Box 1125-30100, Eldoret, Kenya \\ ${ }^{2}$ International Crops Research Institute for Semi-Arid Tropics (ICRISAT), P. O. Box 39063-00623, \\ Nairobi, Kenya \\ ${ }^{3}$ Kenya Agricultural and Livestock Research Organization (KALRO), P.O. Box 169-50100, \\ Kakamega, Kenya \\ ajosephinesarah4@gmail.com, bd.odeny@cgiar.org, cgeorgedangasuk@yahoo.com, \\ dlexa111@hotmail.com, echrisoduori@yahoo.com
}

Keywords: Ethrel, Diallel, Hybrids, Gametocide, Male sterility, CMS

\begin{abstract}
Finger millet is a staple food crop of many communities in Africa. The crop is highly nutritious and has incredible grain storage quality. Limited research investment in finger millet in the past has resulted in poor yields and there are currently no commercial hybrids. We investigated the response of different finger millet genotypes (Okhale-1, Gulu-E, KACCIMMI-72, IE 2872, IE 4115 and U-15) to the application of a plant growth regulator hormone (Ethrel). Six elite Kenyan finger millet varieties with contrasting agronomic traits were crossed in a $6 \times 6$ diallel pattern. To enhance male sterility across female parents, we subjected the plants to Ethrel at concentrations of 1,500ppm, 1,750ppm and 2,000ppm against a 0ppm check. Dwarfing of sprayed plants that resulted in less lodging and ultimately higher yields were observed among plants sprayed with Ethrel at different concentrations. Ethrel application at 2,000ppm had the most dwarfing effect on plants while spraying plants with 1,500ppm of Ethrel resulted in increased grain weight. Although our results demonstrate overall positive effect of Ethrel on finger millet production, the optimum concentrations for more efficient hybridization will still need to be determined.
\end{abstract}

\section{INTRODUCTION}

Finger millet (Eleusine coracana, L. Gaertn) is an important staple traditional food crop belonging to Poaceae family, Chloridoidae subfamily [1]. It is widely grown in different environments of Africa and Asia, and is reported to tolerate soils with $\mathrm{pH}$ of 5.0-8.2 [2]. In Africa, it is cultivated mainly in central, southern and eastern parts [3], where it serves as a subsistence and food security crop [4]. Finger millet grain is highly nutritious with excellent micronutrient composition. The levels of calcium, dietary fibre, polyphenols, amino acid (methionine and cysteine) and fat in finger millet grain are higher than in other commonly used grains such as maize (Zea mays), rice (Oryza sativa), and sorghum (Sorghum bicolor) [3,5]. Due to its nutritional importance, finger millet is gaining popularity among communities in both Africa and Asia [4].

Although consumption demand for finger millet is increasing, yield on farmer's field is low, at about $15-16 \%$ of its potential in Kenya [6]. Genetic improvement has been limited by the difficulties associated with hybridization, particularly emasculation [7]. Cereal crop performance can be optimized through the development of hybrids, application of fertilizer and/or growth regulators [8], among other management practices. Although hybrid seed production technology has been successful in several allogamous cereal crops (maize, sorghum), the results have not been replicated in autogamous cereal crops such as wheat, rice [9] and finger millet. Minimal attempts have been made previously to generate commercial hybrids in finger millet and there are no known reports of commercial scale hybrid seed production. Finger millet's tiny floral architecture is partly responsible for the difficulties experienced in the hybridization. 
The most desirable and commercially viable hybrid seed production technology in plants is the use of cytoplasmic male sterility, which has not been reported so far in finger millet. Most emasculation techniques previously employed in finger millet hybridization have been mechanical, labour intensive, time consuming, required a lot of experience, and very inefficient [10]. The use of chemicals such as Ethrel (ETH; 2-chloroethylphosphonic acid, also known as ethephon) gametocide has been suggested as a valuable time and labour saving resource compared to hand emasculation $[11,12]$, even though the success rate is too low to justify its use for commercial hybrid seed production. Indeed, recent investigations on the use of Ethrel in finger millet [7] resulted in the production of some hybrids. Other benefits to using Ethrel include the reduction in plant height, which leads to reduced lodging, and increased grain yield [13-16].

Ethrel is an ethylene releasing agent that undergoes a physicochemical (non-biological) reaction at a $\mathrm{pH}>3.5$ producing ethylene and phosphoric acid [17]. It is among the few chemicals that contain gametocidal properties used to induce male sterility in crops [18]. Gametocidal effect results in the retardation of anthers for a period of 7 days before pollen release [19]. Ethrel has been previously used in finger millet and pearl millet (biological name) and successfully caused male sterility without affecting female fertility when applied at appropriate developmental stage [7]. The potential of Ethrel to produce 100\% sterility in hybrid wheat (Triticum aestivum L.) when applied at appropriate concentrations has been similarly reported [20]. Although several studies have reported increased yields upon application of Ethrel [21-23], no studies have been performed to determine the specific effects of its application on the crop's agronomic traits. The current study investigated the likely agronomic effects of using Ethrel as a gametocide in finger millet.

\section{MATERIALS AND METHODS}

\section{Plant Material}

Six finger millet varieties (Table 1) were planted in plastic pots in the glasshouse at KALRO-Kakamega, Kenya. The pots were filled with Dystro-mollic Nitosol soil and planted with a minimum of five seeds per pot. Top dressing was done at two weeks after planting using DAP (Kenya National Cereal Board, Kenya) [24]. A total of 4 pots (each pot containing two plants) were maintained per genotype per cross. The crossing was done to achieve a $6 \times 6$ diallel scheme with reciprocals. In total, two hundred and forty pots were used. Regular watering was done to achieve the required moisture content for optimum growth. The planting was done in a staggered manner to achieve synchrony in flowering. The experiment was laid out as a factorial treatment in a completely randomized design (CRD).

Table 1. Characteristics of the parental lines used in the crossing to test efficiency of male sterility induction using Ethrel

\begin{tabular}{|c|c|c|c|c|}
\hline Variety & Code & $\begin{array}{l}\text { Origin and } \\
\text { Source }\end{array}$ & $\begin{array}{l}\text { Striga } \\
\text { Resistance }\end{array}$ & Blast Resistance \\
\hline IE 2872 & IE 2872 & ICRISAT & Resistant & Susceptible \\
\hline IE 4115 & IE 4115 & ICRISAT & Resistant & Resistant \\
\hline GULU-E & GE & Uganda & Resistant & $\begin{array}{l}\text { Moderately } \\
\text { resistant }\end{array}$ \\
\hline KACIMMI 72 & KA-72 & KALRO & Resistant & Resistant \\
\hline OKHALE-1 & OK-1 & Nepal & Resistant & $\begin{array}{l}\text { Moderately } \\
\text { resistant }\end{array}$ \\
\hline $\mathrm{U}-15$ & U-15 & Uganda & Resistant & Resistant \\
\hline
\end{tabular}




\section{Ethrel Application}

All plants to be used as female parents in each pair were sprayed with Ethrel at Zadoks development stage 45, found most effective [7]. Ethrel concentrations of 1,500ppm, 1,750ppm and $2,000 \mathrm{pm}$ were applied to all female parents alongside controls. Each concentration was sprayed on 2 plants per genotype. Chemical application was done using a 2-litre hand sprayer to dripping wetness of the plant [7]. All sprayed plants were labeled accordingly with gametocide concentration level and date of application. When heads emerged on the main stalk, they were covered using a pollination bag. The plants were monitored daily towards flowering and were pollinated with the designated male parent pollen immediately the stigmas stuck out. At maturity, the bagged heads were harvested independently, dried, threshed and seeds packed and stored safely. Data was scored on basic agronomic traits for all plants in order to determine any likely effects of Ethrel on finger millet

\section{Measured Variables and Data Analysis}

The measured variables included days to heading (DH), days to anthesis (DA), days to maturity (DM), ear exertion length (EE), plant height at maturity $(\mathrm{PH})$, grain weight $(\mathrm{GW})$ and productive tiller numbers (PT). The data collected were subjected to analysis of variance (ANOVA) using general linear models (GLM) and means separated by Fischer's protected least significant differences $(\mathrm{p} \leq 0.05)$ resident in SAS 8.2 statistical package [25].

\section{RESULTS}

\section{Effect of Ethrel on Finger Millet Agronomic Traits}

Means showing Ethrel effect on days to heading, days to anthesis, days to maturity, productive tillers, plant height, ear exertion and grain weight across the four gametocide levels (female plants) together with male parent plants are presented in Table 2. There was no effect of Ethrel on the number of days taken to heading, days to anthesis and days to maturity (Table 2).

Table 2: Performance of parental lines following Ethrel spraying under glasshouse conditions

\begin{tabular}{|c|c|c|c|c|c|c|c|c|c|}
\hline Variety & Sex & $\begin{array}{l}\text { Ethrel } \\
(\mathrm{ppm})\end{array}$ & $\begin{array}{l}\text { DH } \\
\text { (days) }\end{array}$ & $\begin{array}{l}\text { DA } \\
\text { (days) }\end{array}$ & $\begin{array}{l}\text { DM } \\
\text { (Days) }\end{array}$ & $\begin{array}{l}\mathbf{E E} \\
(\mathbf{m m})\end{array}$ & $\begin{array}{l}\text { PH } \\
\text { (cm) }\end{array}$ & $\begin{array}{c}\mathrm{GW} \\
(\mathrm{gms})\end{array}$ & NPT \\
\hline \multirow[t]{6}{*}{ IE 2872} & Female & 0 & 56.00 & 68.00 & 110.00 & 94.60 & 92.70 & 11.40 & 1.70 \\
\hline & & 1,500 & 56.00 & 68.00 & 110.00 & 26.70 & 75.50 & 11.60 & 2.10 \\
\hline & & 1,750 & 56.00 & 68.00 & 110.00 & 22.80 & 70.30 & 11.50 & 2.10 \\
\hline & & 2,000 & 56.00 & 68.00 & 110.00 & 13.70 & 65.30 & 10.10 & 2.80 \\
\hline & & $\begin{array}{l}\text { Grand } \\
\text { Mean }\end{array}$ & 56.00 & 68.00 & 110.00 & 39.45 & 75.95 & 11.15 & 2.18 \\
\hline & Male & $\begin{array}{l}\text { Grand } \\
\text { Mean }\end{array}$ & 56.00 & 68.00 & 119.00 & 107.38 & 94.00 & 8.43 & 0.78 \\
\hline \multirow[t]{6}{*}{ IE 4115} & Female & 0 & 67.00 & 79.00 & 121.00 & 106.00 & 95.80 & 9.30 & 1.90 \\
\hline & & 1,500 & 67.00 & 79.00 & 121.00 & 18.80 & 70.80 & 10.80 & 2.50 \\
\hline & & 1,750 & 67.00 & 79.00 & 121.00 & 18.10 & 72.30 & 11.30 & 2.30 \\
\hline & & 2,000 & 67.00 & 79.00 & 121.00 & 27.1 & 72.60 & 11.00 & 3.00 \\
\hline & & $\begin{array}{l}\text { Grand } \\
\text { Mean }\end{array}$ & 67.00 & 79.00 & 121.00 & 42.5 & 77.88 & 10.60 & 2.43 \\
\hline & Male & $\begin{array}{l}\text { Grand } \\
\text { Mean }\end{array}$ & 67.00 & 79.00 & 121.00 & 114.93 & 96.75 & 7.55 & 1.03 \\
\hline \multirow[t]{6}{*}{ GULU-E } & Female & 0 & 67.00 & 79.00 & 122.00 & 92.10 & 93.40 & 10.20 & 1.90 \\
\hline & & 1,500 & 67.00 & 79.00 & 122.00 & 24.10 & 81.00 & 12.70 & 1.90 \\
\hline & & 1,750 & 67.00 & 79.00 & 122.00 & 20.40 & 77.20 & 11.10 & 2.00 \\
\hline & & 2,000 & 67.00 & 79.00 & 122.00 & 17.90 & 76.49 & 10.60 & 2.30 \\
\hline & & $\begin{array}{l}\text { Grand } \\
\text { Mean }\end{array}$ & 67.00 & 79.00 & 122.00 & 38.63 & 82.02 & 11.15 & 2.03 \\
\hline & Male & Grand & 67.00 & 79.00 & 122.00 & 110.53 & 105.05 & 8.68 & 0.90 \\
\hline
\end{tabular}




\begin{tabular}{|c|c|c|c|c|c|c|c|c|c|}
\hline \multirow{2}{*}{ K-72 } & \multirow[b]{2}{*}{ Female } & \multicolumn{8}{|l|}{ Mean } \\
\hline & & 0 & 67.00 & 79.00 & 121.00 & 105.30 & 96.50 & 10.10 & 2.10 \\
\hline & & 1,500 & 67.00 & 79.00 & 121.00 & 19.50 & 82.60 & 12.10 & 1.80 \\
\hline & & 1,750 & 67.00 & 79.00 & 121.00 & 23.10 & 79.50 & 12.00 & 2.00 \\
\hline & & 2,000 & 67.00 & 79.00 & 121.00 & 23.60 & 71.70 & 11.00 & 2.30 \\
\hline & & $\begin{array}{l}\text { Grand } \\
\text { Mean }\end{array}$ & 67.00 & 79.00 & 121.00 & 42.88 & 82.58 & 11.30 & 2.05 \\
\hline & Male & $\begin{array}{l}\text { Grand } \\
\text { Mean }\end{array}$ & 67.00 & 79.00 & 121.00 & 129.50 & 106.25 & 8.78 & 0.75 \\
\hline \multirow[t]{6}{*}{ Okhale-1 } & Female & 0 & 67.00 & 79.00 & 122.00 & 105.5 & 105.30 & 8.70 & 1.70 \\
\hline & & 1,500 & 67.00 & 79.00 & 122.00 & 28.30 & 78.50 & 11.80 & 2.10 \\
\hline & & 1,750 & 67.00 & 79.00 & 122.00 & 14.90 & 72.60 & 11.20 & 2.40 \\
\hline & & 2,000 & 67.00 & 79.00 & 122.00 & 18.00 & 75.90 & 11.60 & 2.20 \\
\hline & & $\begin{array}{l}\text { Grand } \\
\text { Mean }\end{array}$ & 67.00 & 79.00 & 122.00 & 41.678 & 83.08 & 10.83 & 2.10 \\
\hline & Male & $\begin{array}{l}\text { Grand } \\
\text { Mean }\end{array}$ & 67.00 & 67.00 & 122.00 & 120.95 & 104.05 & 8.23 & 1.18 \\
\hline \multirow[t]{6}{*}{ U-15 } & Female & 0 & 61.00 & 73.00 & 115.00 & 104.50 & 94.10 & 10.20 & 2.40 \\
\hline & & 1,500 & 61.00 & 73.00 & 115.00 & 30.50 & 73.40 & 12.60 & 2.20 \\
\hline & & 1,750 & 61.00 & 73.00 & 115.00 & 24.50 & 73.00 & 12.10 & 2.00 \\
\hline & & 2,000 & 61.00 & 73.00 & 115.00 & 25.60 & 73.29 & 11.50 & 2.40 \\
\hline & & $\begin{array}{l}\text { Grand } \\
\text { Mean }\end{array}$ & 61.00 & 73.00 & 115.00 & 46.28 & 78.48 & 11.60 & 2.25 \\
\hline & Male & $\begin{array}{l}\text { Grand } \\
\text { Mean }\end{array}$ & 61.00 & 73.00 & 115.00 & 127.73 & 95.15 & 11.18 & 1.20 \\
\hline
\end{tabular}

$\overline{D H}=$ days to heading; $D A=$ days to anthesis; $\quad D M=$ days to maturity; $\quad G L=$ gametocide level; $E E=$ ear exertion; $P H=$ plant height $; \quad G W=$ grain weight $; \quad N P T=$ number of productive tillers

The highest effect of Ethrel application was observed under ear exertion length. All sprayed plants had shorter ear exertion lengths than the female controls and plants used as male parents (unsprayed), although there was no significant difference between ear exertion length reductions at different gametocide concentrations (Fig. 1).

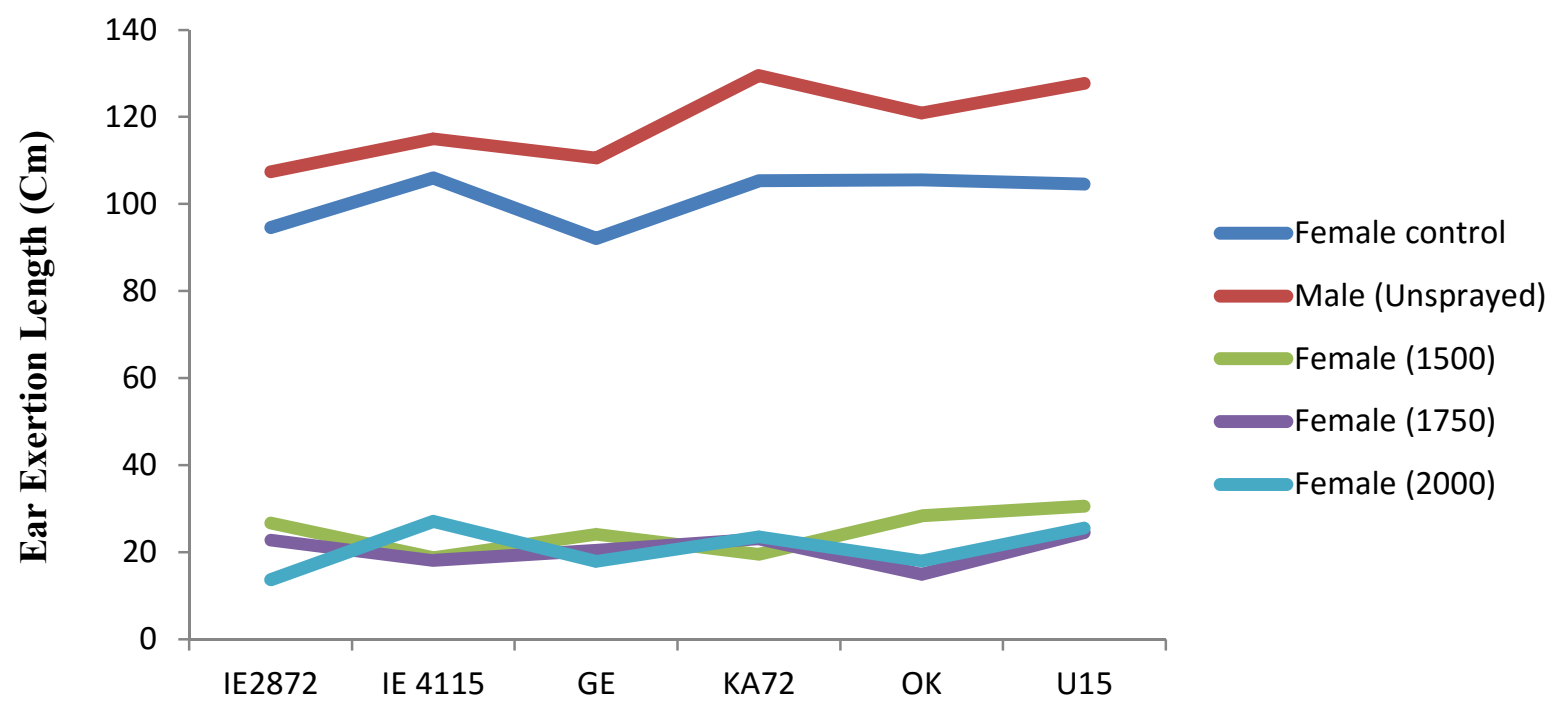

Finger Millet Genotypes

Fig. 1. Comparing ear exertion length between different finger millet genotypes treated with different gametocide concentrations alongside controls 
The male untreated parents also had higher ear exertion length compared to the treated female plants (Table 2). The gametocide further led to the reduction in plant height (Fig. 2) even though there was no significant difference in plant height reduction across the 3 gametocide treatments. The reduction in height was beneficial as it resulted in reduced lodging in comparison to untreated plants. Ethrel treated plants of 4 genotypes (IE4115, Gulu-E, KA72, OK and U-15) resulted in higher grain weight (Fig. 3, Table 2) but not in genotype IE2872 suggesting genotypespecific response to gametocide application. The difference was more pronounced between controls and plants sprayed with $1,500 \mathrm{ppm}$ of the gametocide (Fig. 3A) as opposed to those sprayed with higher concentrations (Fig. 3B and 3C). No comparison was made between grain weight of control female plants and male parents due to the effect of pollen harvesting, which would have resulted in unfair comparison with the male parents. Higher numbers of productive tillers were observed (Table 2) in treated plants, especially at 2,000 ppm across all genotypes except in IE2872 (Table 2).

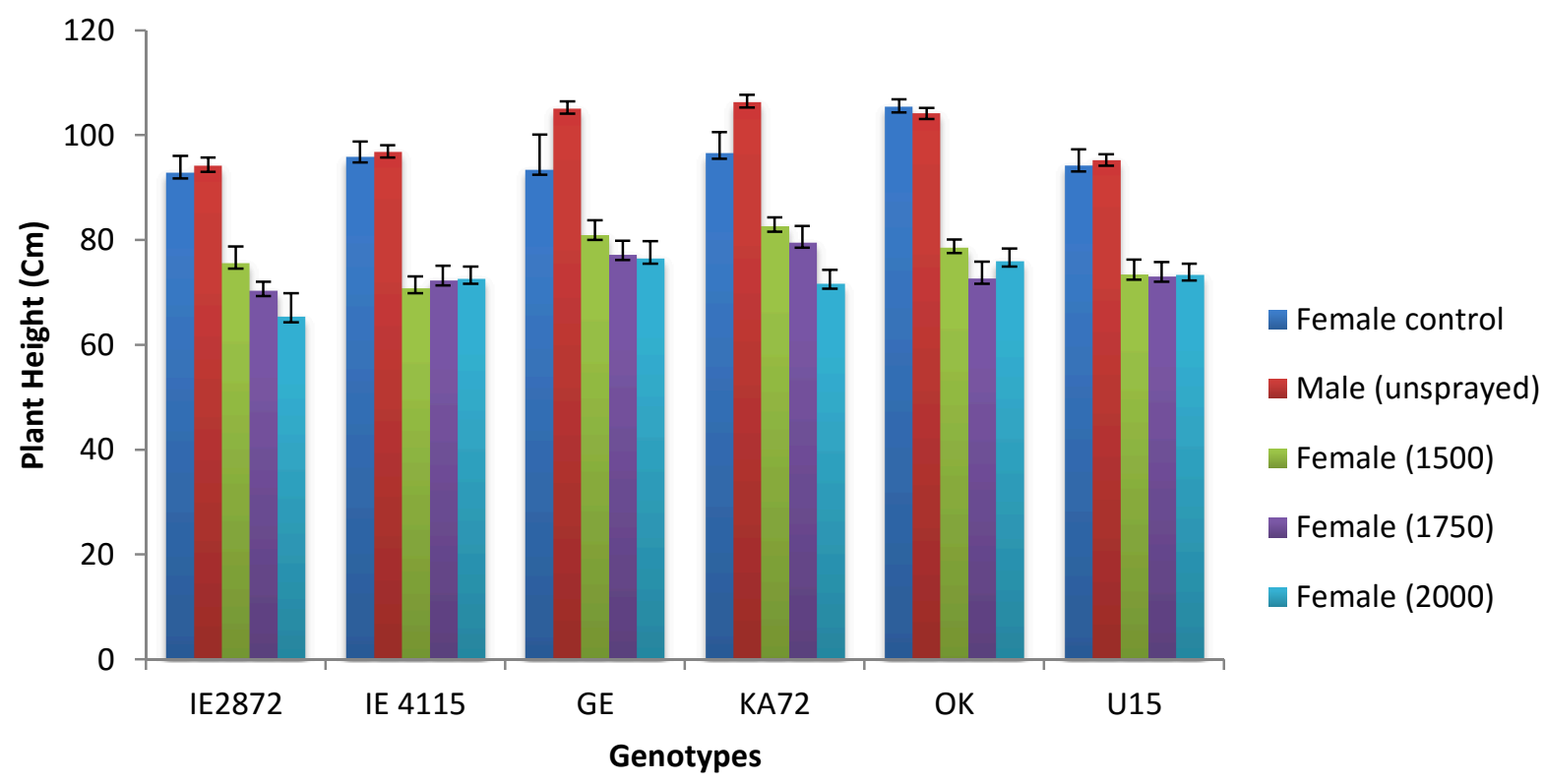

Fig. 2. Comparing plant height in six different finger millet genotypes across different gametocide treatments. The male plants were not treated and were used as pollen sources for crossing with the female plants 


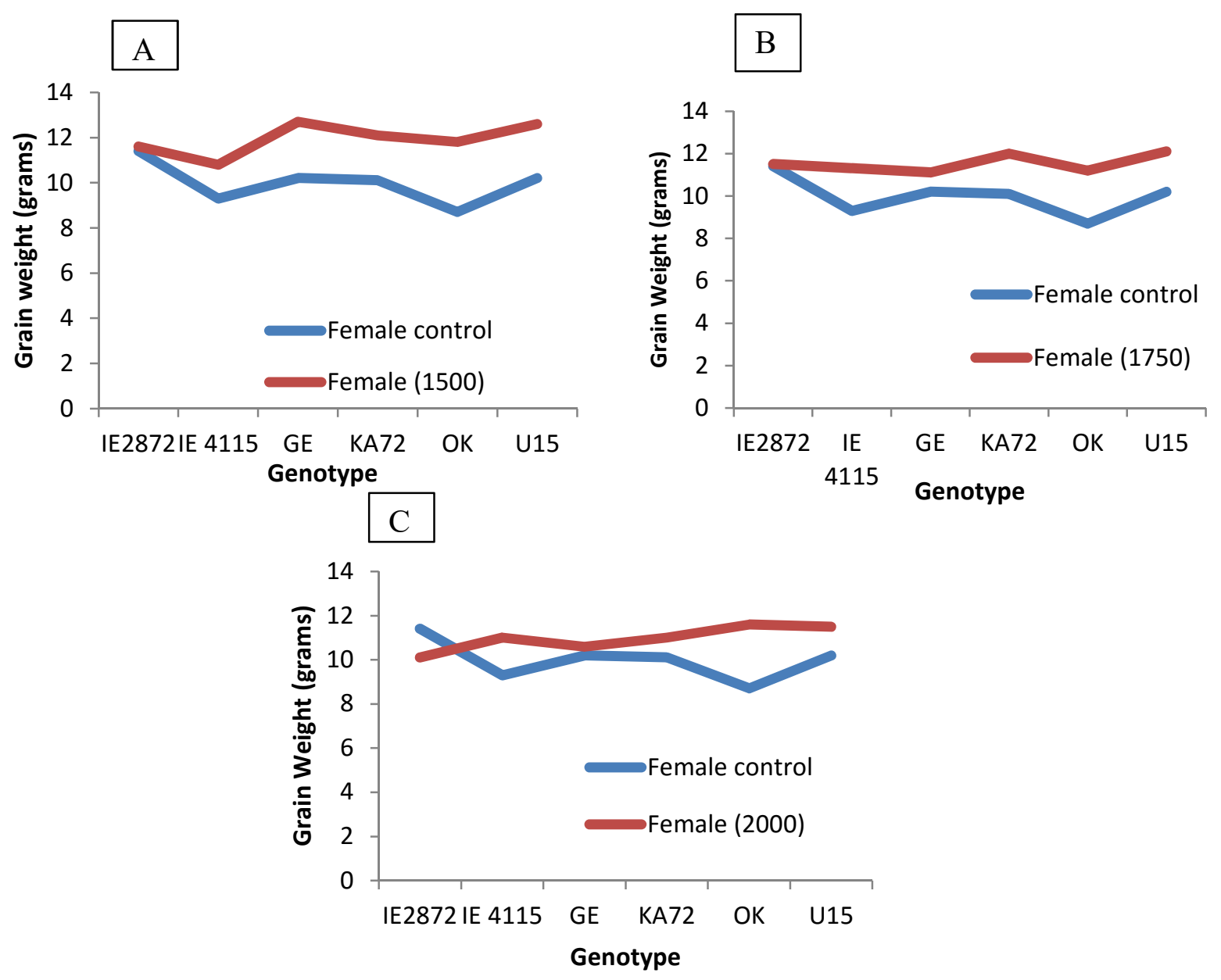

Fig. 3. Differences between grain weight of different genotypes treated with various gametocide concentrations in comparison with controls. No significant difference was observed for genotype IE2872 between controls and treatment with $1,500 \mathrm{ppm}$ (A) or $1,750 \mathrm{ppm}$ (B). At 2,000ppm treatment, IE2872 showed reduction in grain weight in comparison with control. Genotypes IE4115 and OK displayed positive observable grain weight difference even at 2,000ppm

ANOVA (Table 3) revealed significant treatment (gametocide levels) effect on the resulting plant height, ear exertion length and grain weight but not for productive tiller numbers. Expectedly, a significant genotype effect was observed for plant height and grain weight differences. There was significant gametocide level x Genotype interaction for plant height but not for the numbers of productive tillers, ear exertion length and grain weight. The mean squares showing effect of Ethrel on plant height, ear exertion, grain weight and productive tillers across genotypes, gametocide levels and sex of the plant are presented in Table 4. Differences in plant height and ear exertion were observed between male and female parents (Table 2).

Table 3: Analysis of variance mean squares for finger millet agronomic traits as influenced by gametocide level

\begin{tabular}{llllll}
\hline \multicolumn{6}{c}{ Mean Squares } \\
\hline Source & df & $\begin{array}{l}\text { Plant } \\
\text { Height }\end{array}$ & $\begin{array}{l}\text { Productive } \\
\text { Tillers }\end{array}$ & $\begin{array}{l}\text { Ear Exertion } \\
\text { Length }\end{array}$ & $\begin{array}{l}\text { Grain } \\
\text { Weight }\end{array}$ \\
\hline GL & 3 & $7084.01^{* *}$ & $1.3270^{\mathrm{ns}}$ & $99253.9^{* *}$ & $46.712^{* *}$ \\
Genotype & 5 & $1326.10^{* *}$ & $1.9133^{\mathrm{ns}}$ & $647.2^{\mathrm{ns}}$ & $20.527^{* *}$ \\
GL x Genotype & 15 & $207.74^{* *}$ & $0.6756^{\mathrm{ns}}$ & $538.6^{\mathrm{ns}}$ & $5.580^{\mathrm{ns}}$ \\
Error & 213 & 65.04 & 0.8508 & 432.3 & 2.721 \\
Total & 236 & & & & \\
\hline not significant, & & & \\
\end{tabular}


Table 4: Screenhouse agronomic trait mean squares under different gametocide levels (GL) across six finger millet varieties per plant

\begin{tabular}{lllll}
\hline $\begin{array}{l}\text { Source of } \\
\text { variation }\end{array}$ & Plant height & Ear Exertion & Grain weight & NPT \\
\hline Genotypes $(\mathrm{G})$ & $1299.0^{* *}$ & $828.8^{\mathrm{ns}}$ & $20.1^{* *}$ & $1.8^{\mathrm{ns}}$ \\
GL $(\mathrm{ppm})$ & $6827.1^{* *}$ & $96415.7^{* *}$ & $45.6^{* *}$ & $1.3^{\mathrm{ns}}$ \\
& & & & \\
Sex (Female/male) & $105.4^{* *}$ & $160.1^{* *}$ & $1.7^{\mathrm{ns}}$ & $0.2^{\mathrm{ns}}$ \\
$\mathrm{CV} \%$ & 10.1 & 49.8 & 14.9 & 43.8 \\
\hline
\end{tabular}

\section{DISCUSSION}

Finger millet hybridization is tedious and difficult when hand emasculation is employed. Chemical emasculation has proved to be an effective technique to be adopted in generation of hybrids especially in 100\% self-pollinating crops. In the current study, we tested different concentrations of Ethrel and observed their likely effects on the resulting agronomic traits. Other than the desired effect of increasing levels of hybridization rates among treated plants that were used as female parents, Ethrel-treated plants also resulted in higher yields, demonstrating the overall positive effect of Ethrel on finger millet. The use of chemical gametocides is also advantageous in inducing male sterility because any parent plant can be used as a female parent [26].

Ethrel applied at the various concentrations in this study had no significant physiological effect on days to heading, anthesis and maturity. These results were in agreement with previous findings in finger millet [7] and barley [27, 28]. This indicates that Ethrel could be used at any point without interfering with flowering or maturity period in finger millet. Other studies have reported delayed flowering and maturity in maize [29], delayed heading in wheat [30] and also delayed heading in barley [31].

The most significant effect of Ethrel on finger millet in the current study was the reduction of lodging as a result of reduced plant height, with IE2872 being the most affected. Similar results have been reported in wheat [20, 30, 31, 32] treated with Ethrel. Plant growth regulators have been used in several studies in the past to enhance dwarfing and reduce lodging [33,34]. Dwarfing trait is very important in cereals that are prone to lodging, for example rice, wheat and finger millet. Major advances in rice and wheat breeding have led to the introduction of semi-dwarfing genes during the Green revolution [35] resulting in higher yields. The ultimate target in finger millet breeding should be the introduction of similar semi-dwarfing genes to improve yields as was done in rice and wheat. Meanwhile breeders can make use of the positive effect of Ethrel observed in the current study for reducing lodging through the reduction of plant height in finger millet.

Other observed positive effect of Ethrel on plants was increased grain yield as a result of reduced lodging [36]. Plants sprayed with Ethrel showed an increase in total grain weight though with minimal variations compared to female controls and males across genotypes. Ethrel application at $1,500 \mathrm{ppm}$ across the six finger millet genotypes resulted in increased grain weight. The increase in yield was probably due to increased fingers and the number of productive tillers [37]. Studies in other cereals such as maize reported a reduction in grain yield [29] as a result of Ethrel application. Such a contradicting report in maize could be explained by its physiology, which is quite different from that of finger millet.

The gametocide levels used in the current study may appear not to have been optimum but the main target was to achieve decent levels of male sterility in plants to be used as female parents without affecting overall plant physiology and maintaining high levels of female fertility. Other studies that used higher Ethrel concentrations have resulted in adverse physiological effects on the plants [20,38]. The most known effect of Ethrel is poor ear exertion [39], which was also observed in the current study. Although ear length is not a crucial agronomic characteristic, it is important to breeders because poor ear exertion renders cross-pollination difficult [39,7] and hence a reduction in number of hybrids $[20,30,40]$. 


\section{CONCLUSION}

Chemical emasculation in finger millet has proved to be an effective technique to be adopted in creation of hybrids. Ethrel can be used for mass emasculation in finger millet where manual emasculation is impractical [26] due to its tiny floral architecture. Before cytoplasmic male sterility is developed, breeders have the option of using Ethrel in finger millet to generate hybrids with desirable traits in order to improve yields and overall livelihoods of small-scale farmers, who are the major producers of this crop.

\section{References}

[1] Dida, M.M., Srinivasachary, Ramakrishnan, S., Bennetzen, J.L., Gale, M.D. and Devos, K. Population structure and diversity in finger millet (Eleusine coracana) germplasm. Tropical Plant Biol. 1 (2008) 131-141.

[2] ICRISAT/FAO. The world Sorghum and Millet. Economies: Facts, Trends and Outlook. ICRISAT/FAO, 1996.

[3] Obilana, A.B. and Manyasa, E.O Grain properties and utilization potential. Belton PS and Taylor JRN (Eds.). Springer-Verlag (2002) 177-217.

[4] Holt, J. Investigation into the biology, epidemiology and management of finger millet blast in low-input farming systems in E. Africa. (Online) Available at http://www. wisard. org/wisard/shared/asp/projectsummary. asp, 2000.

[5] Devi, P.B., Vijayabharathi, R., Sathyabama, S., Malleshi, N.G. and Priyadarisini, V.B. Health benefits of finger millet (Eleusine coracana L.) polyphenols and dietary fiber: a review. Journal of food science and technology. 51.6 (2014) 1021-1040.

[6] Oduori, C.O.A. Finger millet better varieties-Better crop care-More Food. DFID and GON produced by DEVCOM \& AIC (1998).

[7] Oduori, C.O.A., Tongoona, J., Dereram O. and Odongom M. Finger millet hybridization using ethrel chemical hybridizing agent. In C. O. A. Oduori. Breeding investigations of finger millet characteristics including blast disease and Striga resistance in Western Kenya. Africa Centre for crop Improvement of the University of KwaZulu-Natal, South Africa Ph.D in Plant Breeding, (2008) pp 103-128.

[8] Zaman, M., Kurepin, L.V., Catto, W. and Pharis, R.P. Enhancing crop yield with the use of Nbased fertilizers co-applied with plant hormones or growth regulators. Sci. Food Agric 10.1002 (2014) 6938.

[9] Longin, C.F.H., Mühleisen, J., Maurer, H.P., Zhang, H., Gowda, M. and Reif, J.C. Hybrid breeding in autogamous cereals. Theoretical and applied genetics 125.6 (2012) 1087-1096.

[10] Riley, K.W., Setharam, A. and Harinarayana, G.. Recommendations on breeding and varietal improvement. Small millets in global agriculture. In First International Small Millets Workshop. Bangalore, India: Oxford and IBH Publishing, New Delhi, IN. (1989) p. 29.

[11] Verma, M.M. and Kumar, J. Ethrel-a male gametocide that can replace the male sterility genes in barley. Euphytica 27.3 (1978) 865-868.

[12] Berhe, T. and Miller, D.G. Studies of Ethephon as a possible selective male gametocide on tef. Crop Science. 18 (1978) 35-38.

[13] Dahnous, K., Vigue, G.T., Law, A.G., Konzak, C.F. and Miller, D.G. Height and yield response of selected wheat, barley, and triticale cultivars to ethephon. Agronomy. 74.3 (1982) $580-582$. 
[14] Harms, C.L. Lodging Control in Wheat and Barley with a Plant Growth Regulator. Agronomy Guide AY-261. Purdue Univ. Coop. Extension Service, W. Lafayette, Indiana, USA (1986).

[15] Simmons, S.R., Oelke, E.A, Wiersma, J.V, Lueschen, W.E. and Warnes, D.D. Spring wheat and barley responses to ethephon. Agronomy 80.5 (1988) 829-834.

[16] Boutaraa, T. Effect of drought and ethrel on ultrastructure and some yield components of wheat varieties cultivated in Algeria. ENS, V. Kouba, Algeria, 1991.

[17] Beaudry, R. M., and S. J. Kays. Flux of ethylene from leaves treated with a polar or non-polar ethylene-releasing compound. Journal of the American Society for Horticultural Science (USA) (1988).

[18] Acquaah, G. Breeding peanut. Principles of Plant Genetics and Breeding, Second Edition, 2007, pp 639-646.

[19] Masoudi-Nejad, A., Nasud, S., McIntosh, R.A. and Endo, T.R. Transfer of rye chromosome segments to wheat by a gametocidal system. Chromosome Research 10.5 (2002) 349-357.

[20] Rowell, P.L. and Miller, D.G. Induction of male sterility in wheat with 2chloroethylphosphonic acid (Ethrel). Crop Science 11.5 (1971) 629-631.

[21] Mehdi, M., Ahmed, N., Jabeen, N., Khan, S.H. and Baseerat, A. Effect of ethrel on hybrid seed production of cucumber (Cucumis sativus L.) under open and protected conditions. Asian Horticulture 7.2 (2012) 558-560.

[22] Buttar, G.S., and Sudeep S. "Effect of ethrel dose and time of application on growth, yield and duration of $\mathrm{Bt}$ cotton in semi arid region of Punjab. Journal of Cotton Research and Development. 27.1 (2013) 60-62.

[23] Mahala, P., Choudhary, M.R, Yadav, T.V., Garhwal, O.P. and Singh, P. Effect of plant growth regulators on yield, quality and economics of bottle gourd [Lagenaria siceraria (Mol.) Standl.]. Annals of Agri Bio Research 19.1 (2014) 137-139.

[24] Nyende, P., Tenywa, J.S, Oryokot, J. and Kidoido, M.M. Weed profiles and management assessment for increased finger millet production in Uganda. (2001).

[25] SAS, SAS. STAT® User's guide (release 8.2 ed.). Cary, NC, USA. SAS Inst. (2001).

[26] Chahal, G.S., and Gosal, S.S. Principles and procedures of plant breeding: biotechnological and conventional approaches. Alpha Science Int'1 Ltd., 2002.

[27] Moes, J. and Stobbe, E.H. (1991). Barley treated with ethephon: I. Yield components and net grain yield. Agronomy Journal 83.1 (1991): 86-90.

[28] Al-Jamali, A.F., Turk, M.A., and Tawaha, A.R.M. Effect of ethephon spraying at three developmental stages of barley planted in arid and semiarid Mediterranean locations. Journal of Agronomy and Crop Science. 188.4 (2002) 254-259.

[29] Earley, E.B., Slife and F.W. Effect of ethrel on growth and yield of corn. Agronomy journal. 61.5 (1969) 821-823.

[30] Stoskopf, N.C. and Law, J. Some observations on ethrel as a tool for developing hybrid cereals.Canadian Journal of Plant Science 52.4 (1972) 680-683.

[31] Milliano, D.W. Improvement of wheat in Zambia using incomplete resistance against rusts. Diss. Landbouwhogeschool, 1983.

[32] Adugna, A., Nanda, G.S., Singh, K. and Bains, N.S. A comparison of cytoplasmic and chemically-induced male sterility systems for hybrid seed production in wheat (Triticum aestivum L.). Euphytica. 135.3 (2004) 297-304. 
[33] Straub, R.W. Ethephon growth regulator as a potential tool for managing excessive height in sweet corn hybrids. New York's food and life sciences bulletin (ISSN 0362-0069 129 (1989).

[34] Shekoofa, A., and Emam, Y. Plant growth regulator (ethephon) alters maize (Zea mays L.) growth, water use and grain yield under water stress. Journal of Agronomy 7.1 (2008) 41.

[35] Hedden, P. The genes of the Green Revolution. TRENDS in Genetics 19.1 (2003) 5-9.

[36] Turk, M.A., Rahman, M., Al-Tawaha, A., Nikus, O., and Rifaee, M. Response of six-row barley to seeding sate with or without Ethrel spray in the absence of moisture stress. International Journal of Agriculture \& Biology. Department of Plant Production. Faculty of Agriculture. Jordan University of Science and Technology (JUST). Irbid, Jorda 5.4 (2003) 416-418.

[37] Ravindran, G., Rajagopalan, R., Krishnamoorthy, V.S. and Vijayan, K.P. Correlation and path coefficient analysis in ragi (Eleusine coracana G.). CROP RESEARCH-HISAR- 12 (1996) 359-362.

[38] Whitford, R., Fleury, D., Reif, J. C., Garcia, M., Okada, T., Korzun, V. and Langridge, P. Hybrid breeding in wheat: technologies to improve hybrid wheat seed production. Journal of experimental botany 64.18 (2013) 5411-5428.

[39] Fairey, D.T. and Stoskopf, N.C. Effects of granular ethephon on male sterility in wheat. Crop Science. 15.1 (1975) 29-32.

[40] Law, J. and Stoskopf, N.C. FURTHER OBSERVATIONS ON ETIIEPHON (ETHREL) AS A TOOL FOR DEVELOPING HYBRID CEREALS. Canadian Journal of Plant Science 53.4 (1973): 765-766. 